\title{
Climatic effects and bedrock control on rapid fluctuations of Chhota Shigri glacier, northwest Himalaya, India
}

\author{
Surendar Kumar, D. P. Dobhal \\ Wadia Institute of Himalayan Geology, Dehra Dun 248001, India
}

\begin{abstract}
Active tectonism in the Himalaya, and the long-fault lineament controlling the east-west river valleys, play an important role in melt at the snouts of glaciers, or their fluctuations during the year. Lower glacier limits are controlled by high winds from the Indian plains flowing along the valleys. Fluctuations of the Chhota Shigri glacier depend on temperature variations at the junction with the Chandra River valley and in the unconsolidated morainic debris below the glacier ice. High flow rates in the ablation zone indicate that basal sliding is the main movement mechanism. Melt takes place mainly from advection, and this process of melting during the summer season occurs both day and night.
\end{abstract}

\section{INTRODUCTION}

The Chhota Shigri glacier $\left(32^{\circ} 11^{\prime}-32^{\circ} 8^{\prime} \mathrm{N}\right.$ and $77^{\circ} 30^{\prime}$ $77^{\circ} 33^{\prime} \mathrm{E}$ ) lies within the monsoon arid transition zone (Krenek and Bhawan, 1945) in the Lahaul-Spiti District, Himachal Pradesh, India (Fig. 1). It is considered to be a potentially sensitive indicator of the northern limits and intensity of the monsoon. Its fluctuations, of the order of 19-20 $m$ either advance or retreat, have been observed since 1986 (Kumar and Dobhal, 1994).

Chhota Shigri is a transverse glacier descending $9 \mathrm{~km}$ northwards from the Pir Panjal Range in the main Chandra River valley of Himachal Himalaya. The accumulation zone lies at $4650-5900 \mathrm{~m}$. The equilibrium line (ELA) fluctuates between 4650 and $4800 \mathrm{~m}$. The maximum width of the glacier is $1.5-1.8 \mathrm{~km}$ near the ELA. The snout is narrow, steep, covered by debris and bounded by escarpment walls (Fig. 2), dropping at an angle of $35^{\circ}$ through the ablation zone to the snout at $4100 \mathrm{~m}$ a.s.l.; extending about $1 \mathrm{~km}$ over morainic alluvium deposits. The glacier is fed by four tributaries, three on the eastern side and one on the west. The total glacierized area is $18.6 \mathrm{~km}^{2}$ with ice in the main glacier stream occupying about $8.6 \mathrm{~km}^{2}$. Thickness varies from $15-$ $130 \mathrm{~m}$ from the snout to the accumulation zone (Fig. 3), according to a gravity survey. The average flow velocity is $8.58 \mathrm{~m} \mathrm{a}^{-1}$, ranging from $8.1 \mathrm{ma}^{-1}$ in the ablation zone to $13.81 \mathrm{~m} \mathrm{a}^{-1}$ at the ELA (Dobhal, 1992). The temperature varies from $-4.5^{\circ}$ to $11^{\circ} \mathrm{C}$ at the ELA in August-September to $4.5^{\circ}$ to $19^{\circ} \mathrm{C}$ at the snout. There are no surface streams in the basin; discharge is entirely due to melting of the glacier.

\section{CLIMATE}

The Himalaya form the southern limits of the Tibetan Plateau. This $5-7 \mathrm{~km}$ elevated region has an enormous influence on the natural environment and on its adjacent regions. The high plateau causes many changes in the atmospheric column, such as a differential heating effect which is low near the plateau and warm high above it. It intercepts the sub-tropical planetary high-pressure zone and has a direct affect on the Indian monsoon ( $\mathrm{Li}$ and $\mathrm{Xu}, 1984$ ). During the monsoon months wind speed varies from 10 $20 \mathrm{~m} \mathrm{~s}^{-1}$ in the Himalaya (Fig. 4). The mean 600 mbar chart forJuly 1200 GMT, averaged over the period 1961-70, shows troughs falling over southern Tibet and on the northern and southern sides of the Tibetan plateau (Fig. 5), hence producing glaciers in the Himalaya which are very active. When the westerly circulation is more southerly, and becomes blocked over the plateau in the winter months, the thermodynamic effect causes abundant precipitation, as rain and snow, over the western Himalaya. The Himalayan glaciers are not only large but, lying at very low latitudes, are very temperate.

Table 1. Meteorological characteristics on Chhota Shigri glacier during the summer season (August-September) 1986-89 from field measurements at $3870 \mathrm{~m}$ (station A) and $4650 \mathrm{~m}$ (station $\mathrm{B}$ )

\begin{tabular}{|c|c|c|c|c|}
\hline lears & 1986 & 1987 & 1988 & 1989 \\
\hline \multicolumn{5}{|l|}{ Slation A } \\
\hline \multicolumn{5}{|l|}{ Temperature ( $\mathrm{C}$ ) } \\
\hline Maximum & 17.0 & 19.0 & 19.40 & 17.0 \\
\hline Minimum & 04.5 & 04.5 & 03.2 & 02.0 \\
\hline Average & 11.4 & 12.2 & 12.4 & 13.5 \\
\hline Wind speed $\left(\mathrm{km} \mathrm{h}^{-1}\right)$ & $8-18$ & $8-16$ & $7-16$ & 1219 \\
\hline Wind direction & W & W & W & W \\
\hline Humidity $(\%)$ & $39-84$ & $38-88$ & $51-84$ & $42-86$ \\
\hline Albedo $\left(\mathrm{h} \mathrm{m}^{1}\right.$ ) & - & $3.30-11.5$ & $3.2 .5-12.5$ & $\begin{array}{ll}3.75 & 12.8\end{array}$ \\
\hline \multicolumn{5}{|l|}{ Station B } \\
\hline \multicolumn{5}{|l|}{ Temperature ( $\mathrm{C}$ ) } \\
\hline Maximum & 10.5 & 11.0 & 8.1 & 7.5 \\
\hline Minimum & -4.5 & -1.3 & -5.2 & -1.6 \\
\hline Average & 4.2 & 4.6 & 3.9 & 6.0 \\
\hline Wind speed $\left(\mathrm{km} \mathrm{h}^{-1}\right)$ & $4-12$ & $\begin{array}{ll}5 & 13\end{array}$ & $3-12$ & $4-11$ \\
\hline Wind direction & S & S & S & $\mathrm{S}$ \\
\hline Humidity (\%) & $65-91$ & 6597 & $65-81$ & $60-91$ \\
\hline Albedo $\left(\mathrm{h} \mathrm{m}^{-1}\right)$ & $1.0-1.7$ & $1.0-1.7$ & $1.25-5.50$ & $1.35-5.55$ \\
\hline
\end{tabular}




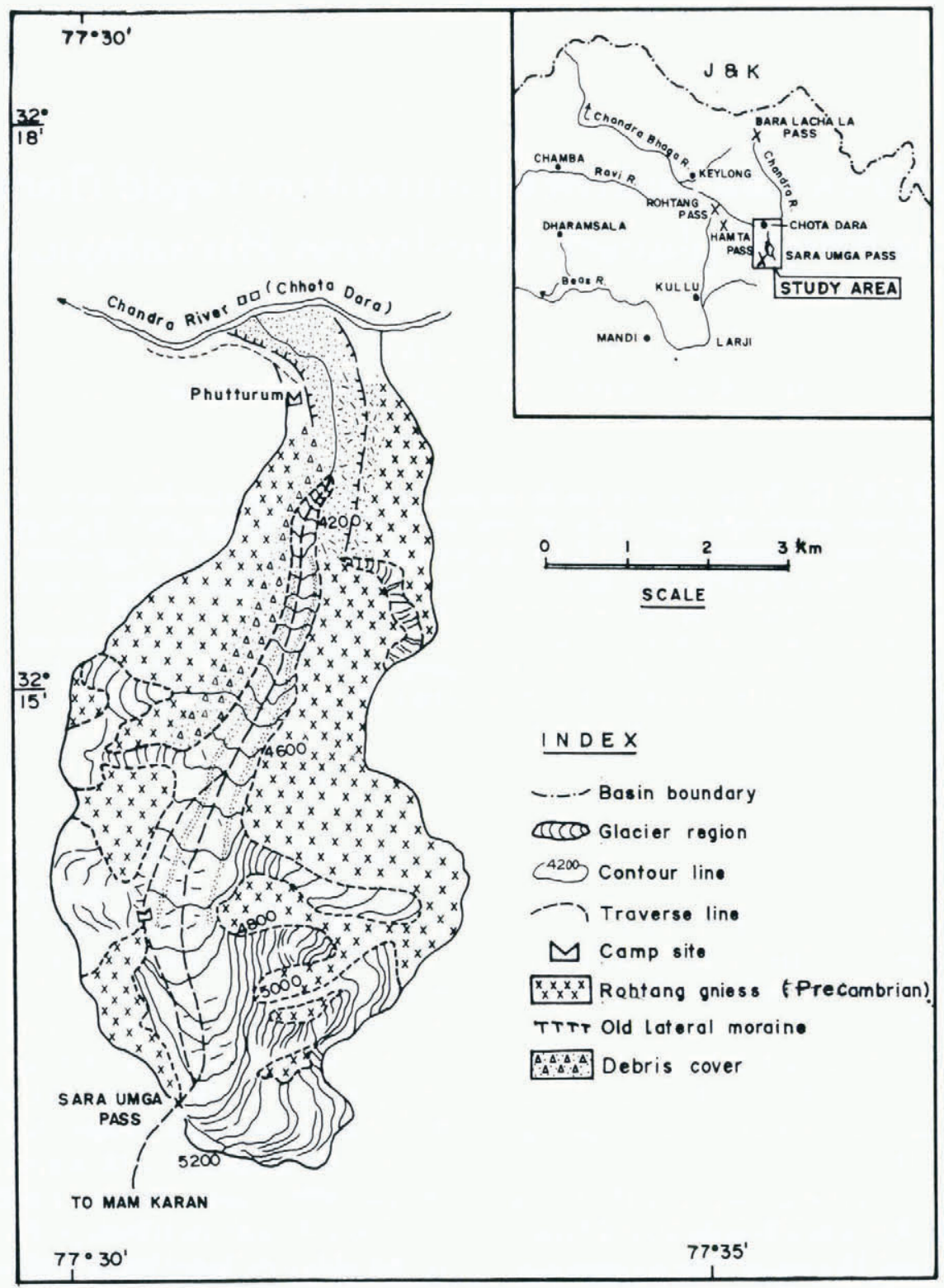

Fig. 1. Location map of the glacier with some salient features of Chhota Shigri glacier.

It is evident that temperature plays an important role in the rapid fluctuations of a glacier. This is indicated by data on mass changes in the Chandra Valley system, collected in 1986-89 (Table 1; stations A and B), which show considerable climatic variation.

The major pattern of the glacier regime controlled by climate has been identified. Glacier melt takes place mainly from advection, and this process of melting during the summer season occurs both day and night. Precipitation increases at low altitudes, below $3870 \mathrm{~m}$ a.s.l., but at $4650 \mathrm{~m}$ the influence of the summer is reduced. Wind flow in the glacier valley is generally from the south and southwest, whereas in the main valley it is mainly westerly where it forms eddy currents (Fig. 6). The temperature here is higher than at the glacier where the melting rate is 2 $4 \mathrm{~cm} \mathrm{~d}^{-1}$. The mass-balance trend was negative for 1987-88

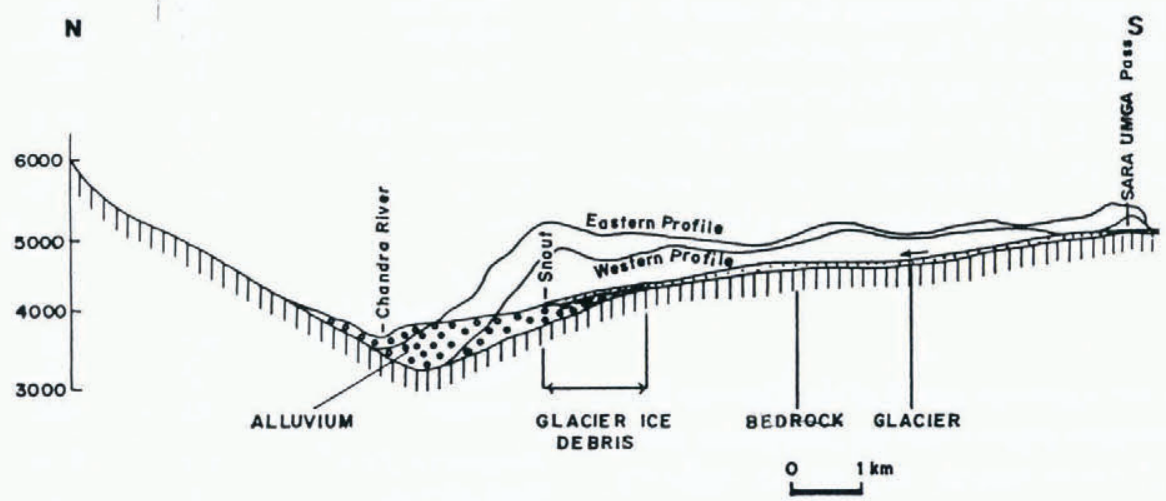

Fig. 2. Longitudinal profile along the eastern and western side of the glacier valley, cross-profile of the valley ( $U$-shaped) showing the toe of the glacier resting on pulverized material. 


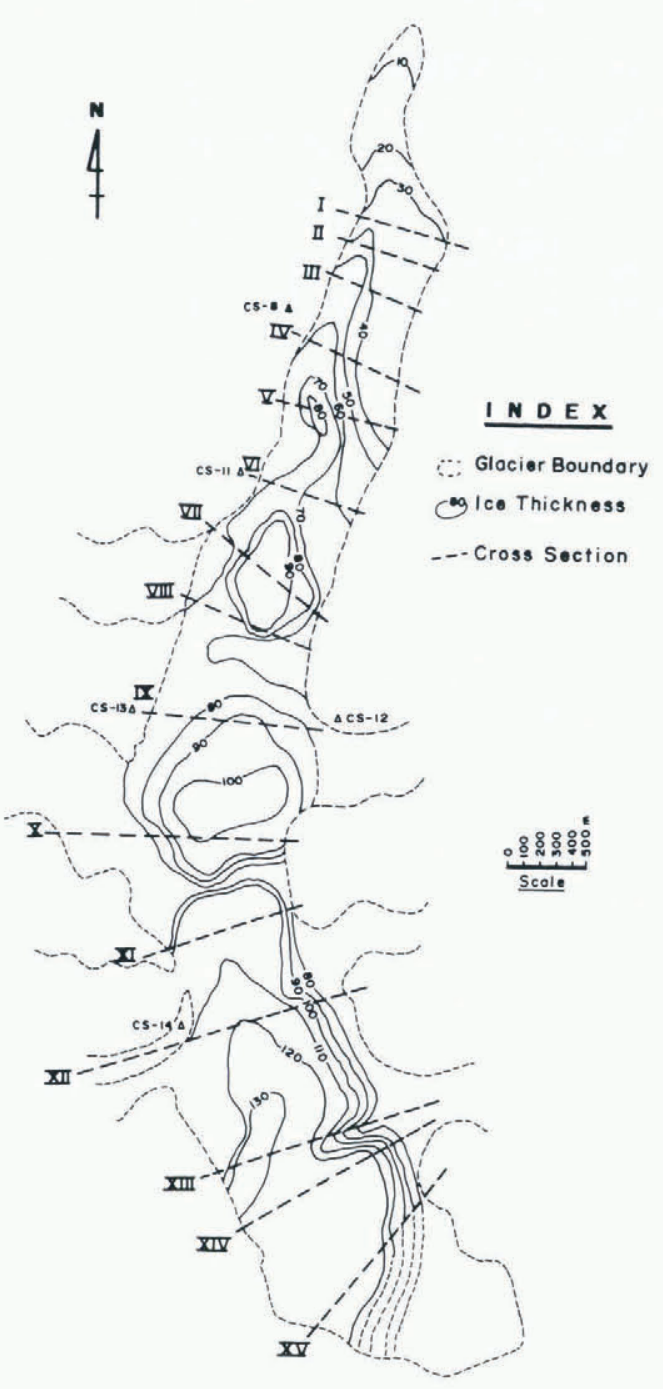

Fig. 3. Thickness of the ice determined by a gravity method in 1988. The ice-depth contour plotted from the ice thickness with a $10 \mathrm{~m}$ contour interval and cross-section XIV taken to calculate the velocity distribution components.

and $1988-89 ;-1.01 \times 10^{6} \mathrm{~m}^{3}$ and $-1.71 \times 10^{6} \mathrm{~m}^{3}$, respectively (Dobhal and others, 1995).

The diurnal variation of temperature is comparatively greater. The temperature is higher in the main Chandra Valley than at the Chhota Shigri glacier, such that the glacier is up to $-1.6^{\circ}$ to $5^{\circ} \mathrm{C}$ cooler in the summer months (August). Mean relative humidity varies from 73 to $93 \%$ in the valley, which is more at the glacier. Energy-budget calculations near the ELA give a snowmelt rate of $0.5 \mathrm{~cm} \mathrm{~d}^{-1}$. The environmental lapse rate ranges from $5.3^{\circ}$ to $14.7^{\circ} \mathrm{C}$

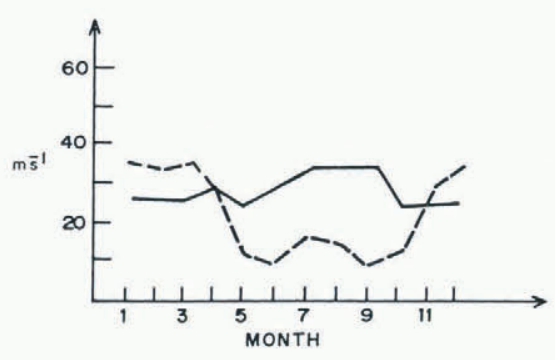

Fig. 4. Annual variation of wind speed at $12 \mathrm{~km}$ on the south (broken line) and north (solid line) side of the plateau (after Gao You-Xi and others, 1981).

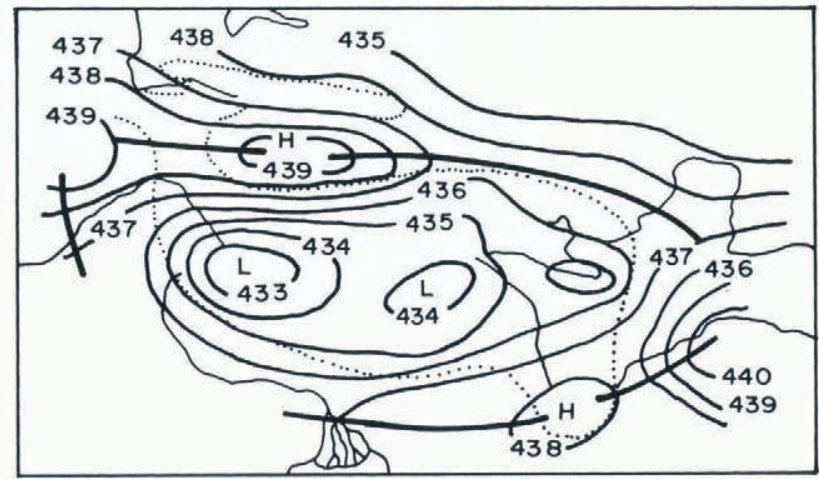

Fig. 5. Mean 600 mbar chart for July averaged over the period 1961-70 in geopotential decameters, 1200 GMT (after Gao You-Xi and others, 1981).

$\mathrm{km}^{-1}$ but is mostly scattered around $12^{\circ} \mathrm{C} \mathrm{km}^{-1}$ (Purohit and others, 1989).

\section{BEDROCK GEOLOGY}

Chhota Shigri glacier lies within the Central Crystallines of the Pir Panjal range of the Himachal Himalaya (Fig. 7). This Crystalline axis is comprised mostly of meso- to ketazonal metamorphites, migmatites and gneisses. In places, granitic rocks of different composition and younger age indicate rejuvenation. But $3 \mathrm{~km}$ upstream of Chhota Dara, in the upper Chandra valley, older Palaeozoic granitic rocks are exposed. The Haimanta Formation overlies these with a tectonic break, where black slates, phyllites and fine-grained biotite-schists are exposed. The slates and phyllites show a well-developed thrust tectonic contact which forms the crest of the northern ridge. Box-type folds with décollement are quite prominent in the Haimanta Formation.

The Haimantas, which rest directly on basement rocks, are highly metamorphosed metasediments and show intense folding and shearing. The brown biotite, with a finegrained texture, shows intense heating effects which indicates periodic reheating of the granitic rocks below. This is also indicated by the various types of granitic and gneissic rocks present in the basement. Schistose gneiss and augen-

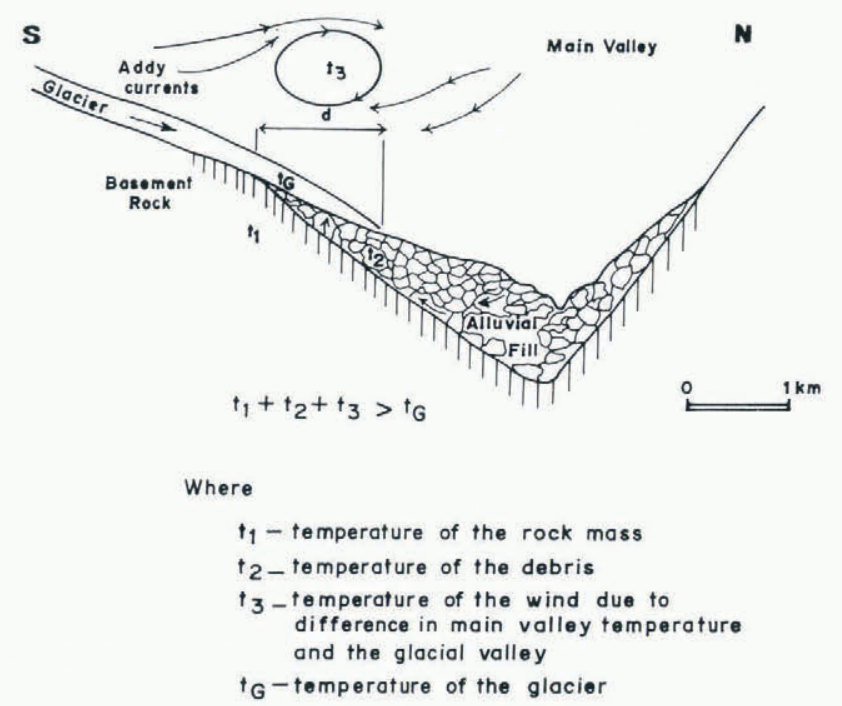

Fig. 6. Formation of the eddy current at the junction of the glacier valley (south and south-southwest) and the main Chandra Valley (westerly) wind-flow direction. 


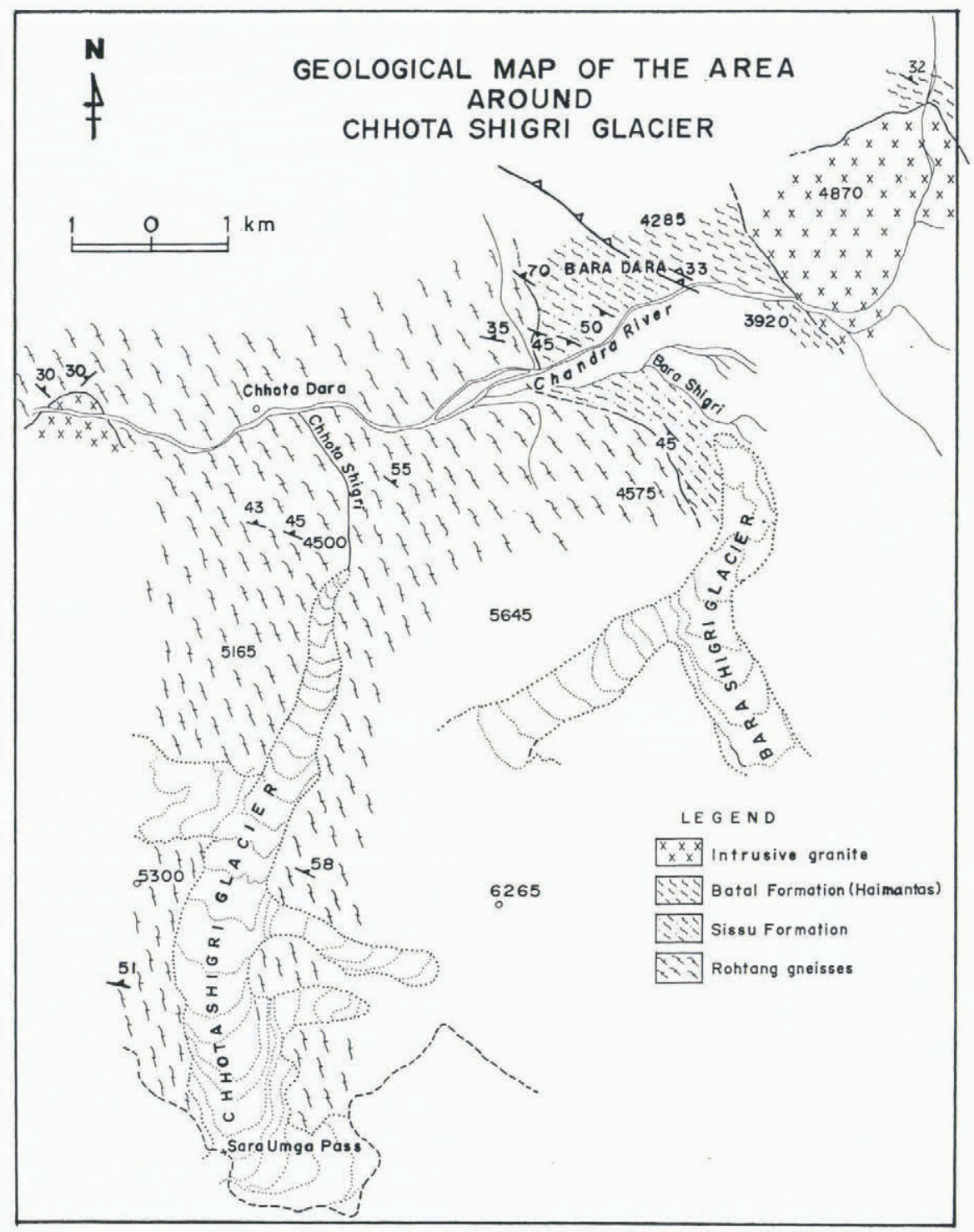

Fig. 7. Geological map of the area around Chhota Shigri glacier (after Rawat and Purohit, 1988).

gneiss have developed in the granite without any distinct margins (Kumar, 1979, 1996). Chhota Shigri glacier rests on the granitic basement rocks

On both sides the ridge tops are at an altitude of $6300 \mathrm{~m}$ and the bottom of the Chandra Valley lies at $3300 \mathrm{~m}$. The overall relief is $3000 \mathrm{~m}$.

\section{GEOMORPHOLOGICAL ASPECTS AND GLAGIAL LIMITS}

Time and again it has been postulated that in this region there are more than three levels of erosion, belonging to more than three different cycles, related to several tectonic events separated from each other in time and space. The erosional features provide a good observational setting for assessing:

1. The influence of the present glaciation on the higher areas and the valley climate.

2. Controls related to bedrock geology and structure.

In the Himalaya, the Neoglacial moraine complexes are generally preserved above the present termini at $4300 \mathrm{~m}$, but this limit varies with the average height of the region. They are quite prominent, sharp and multi-crested, steep- walled complexes up to $150 \mathrm{~m}$ thick and very close to the present glacier snouts. Chhota Shigri glacier has four such sharp crests, which higher up are disturbed by solifluction debris but lower down are disturbed by minor slips within the morainic complex and rockfalls over it. The moraines show a high degree of mechanical weathering due to the extremes of climate. High wind velocities causes desert varnishing. Boulder-faceted soil development in the morainic debris is quite prominent. Considering these characteristics with respect to their position, the moraines can be attributed to a recessional stage of the last glaciation (Fig. 8).

The most interesting observation on the snout of Chhota Shigri glacier and the lower part of the ablation zone is that the section about $800-1000 \mathrm{~m}$ from the snout rests on debris deposited by glacier movement at its toe, i.e. glacial moraine or till (Fig. 6). These moraines are mostly quite thick $(>50 \mathrm{~m})$ and rest on a hard rock base, but in the lowest parts they are $>100 \mathrm{~m}$ thick and represented by a poorly consolidated till. As is clear from Figure 9, the Chhota Shigri glacier moraine has an exceptional crest, higher than the present level of the Chandra River. The latter has three distinct levels of terraces at intervals of $>50 \mathrm{~m}$ (Fig. 9). Glacier flow does not appear to have increased the morainic deposits but there is a crest in the valley which is a recent phenomenon. These moraine levels contain "fresh" boulders exhibiting limited surface weathering. However, the maxi- 


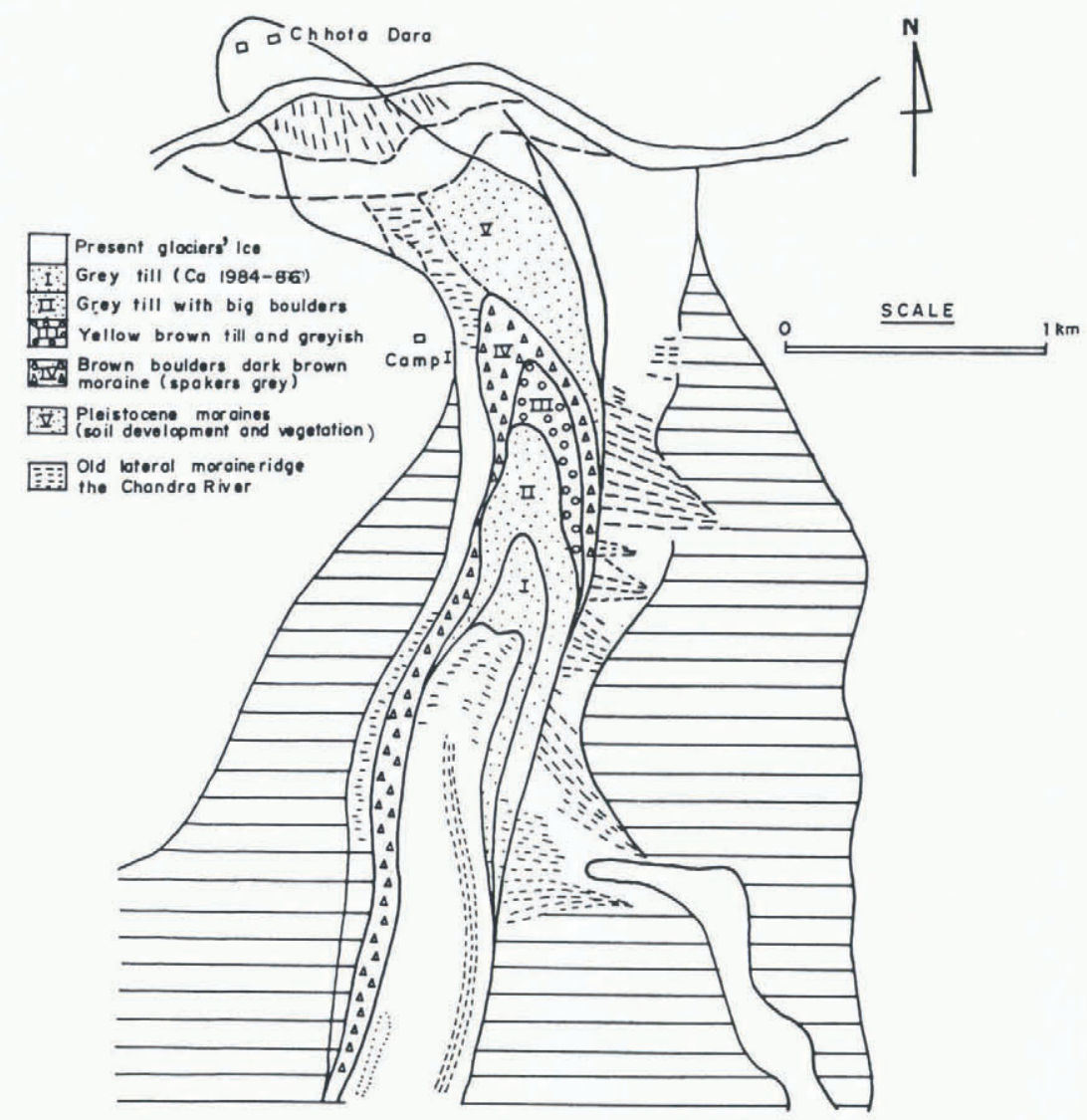

Fig. 8. Five recessional stages of the glacier from last glaciation.

mum advance of the terminal moraines has been correlated with the last glaciation.

\section{DISCUSSION}

It is clear from the climate data that the Himalayan glaciers cannot be compared to the Alpine ones (Table 1). The main difference is the orientation of the mountain ranges. Northto-south cold winds can affect climatic conditions in the Alps, but have a lesser effect in the Himalaya. It is also clear that the orographically controlled climatic gradient due to the Tibetan Plateau, tectonic uplift and contrasting glacier geometries all had a direct affect on the Pleistocene glaciation in the Himalayan region.

Active tectonism in the Himalaya, and the long-fault lineament controlling the east-west river valleys opening to the south of the ranges in the Indo-Gangetic plains, play an important role in controlling melt at the snouts of the glaciers, or the fluctuations during a year. The lower glacier limits, which extend onto the morainic debris, and melt with respect to the variations in the main valley temperatures, are controlled by high winds from the Indian plains flowing along the valleys. While glacier extension is based on snow accumulation in the region and the available snowfields, snout fluctuations depends on temperature variations at the junction of two valleys and in the unconsolidated morainic debris below the glacier ice (Fig. 6). In the Himalaya, few glaciers flow over rocks, most have lower snouts extending over glacial deposits, depending on the extension depth and the shape of the valleys, which further control the glacier shape and geometries.

Calculated velocity-distribution components at different cross-sections of Chhota Shigri glacier are given in Table 2
(Fig. 3). Cross-section VI shows the maximum surface velocity and ice discharge and can be inferred as the equilibrium line, separating the ablation and accumulation zones. Even the extraordinary high rate of $V_{\mathrm{b}} / V_{\mathrm{s}}$ (up to $92 \%$ ) in the ablation zone indicates that basal sliding, controlled by the ice mass and the slope, is the main mechanism of glacier movement. However, the bare upper surface does show some capillary action, i.e. waxing and waning.

\section{GONGLUSION}

The recent study of Chhota Shigri glacier showed a thinning in the middle part by $3 \mathrm{~m}$ during 2 years (i.e. 1987 and 1988). A gravity survey indicated the glacier was compara-

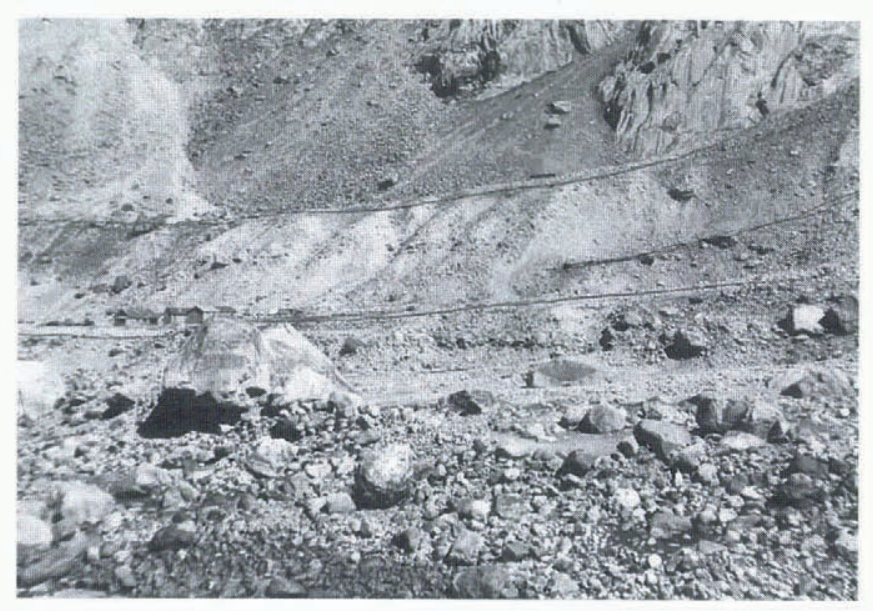

Fig. 9. Three distinct levels of the river terraces of the Chandra River at intervals of 50-60 m. This indicates that Chhota Shigri Glacier has an exceptionally higher crest than the present level of the Chandra River. 
Table 2. Calculated glacier thickness and component velocity along the central line of the glacier in 1987 and 1988 (Dobhal, 1992)

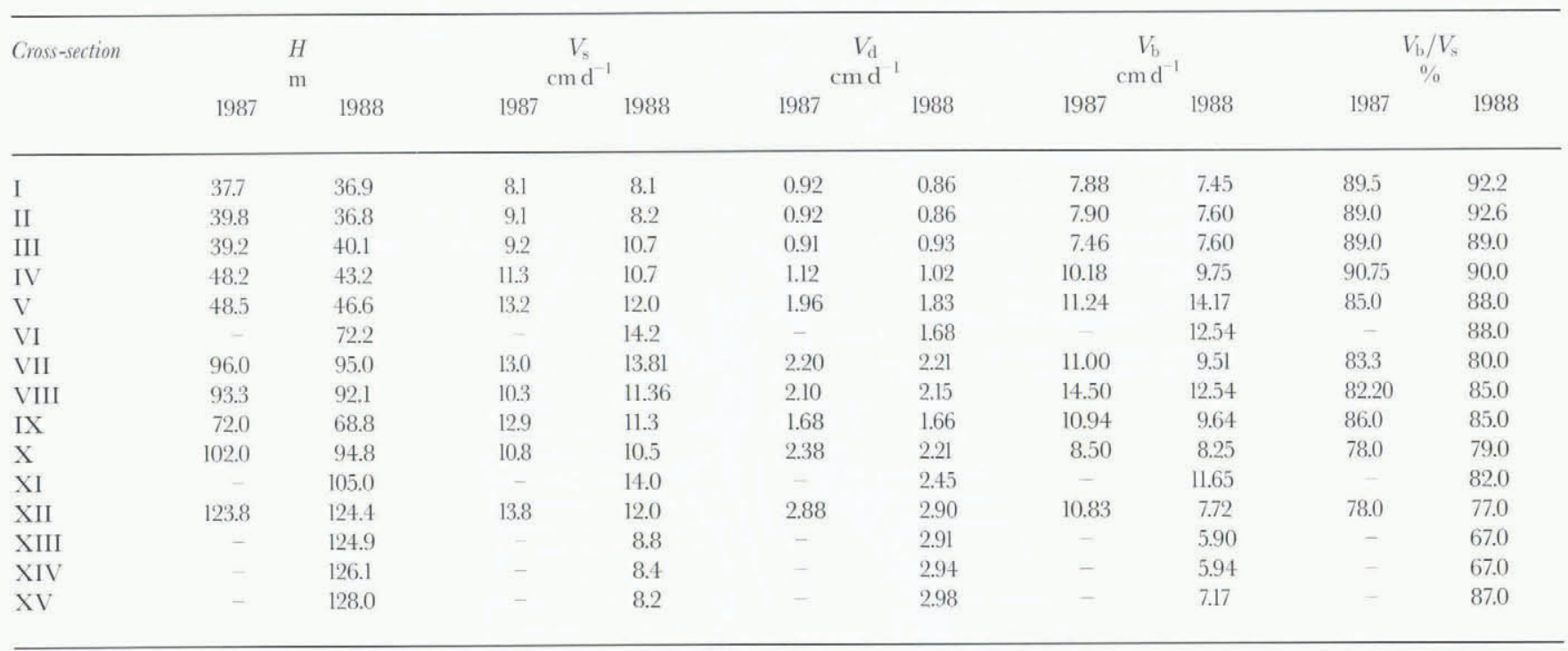

tively thicker on the western side than in the middle part. The maximum thickness of the glacier on the western side indicates the glacier valley is much more inclined or deeper on that side, which may be due to bending of the glacier and more erosion. Regarding the movement of the glacier, the high rate of $V_{\mathrm{b}} / V_{\mathrm{s}}$ in the ablation area indicates that basal sliding is the main movement mechanism, meltwater contributes more to its movement in the north-northeast direction.

\section{ACKNOWLEDGEMENT}

The authors are grateful to the Director, WIHG, Dehra Dun, for the opportunity to carry out the present work. Financial assistance from DST, Ministry of Science and Technology, Government of India, New Delhi, under the Himalayan Glacier Programme, is gratefully acknowledged.

\section{REFERENGES}

Dobhal, D. P. 1992. Inventory of Himachal glaciers and glaciological studies of Chhota Shigri glacier, Himachal Pradesh: a case history. (Ph.D. thesis, H.N.B. Garhwal University, Srinagar, Garhwal.
Dobhal, D. P., S. Kumar and A. K. Mundepi. 1995. Morphology and glacier dynamics studies in monsoon-arid transition zone: an example from Chhota Shigri glacier, Himachal Himalaya, India. Current Sci. (Bangalore), 68(9), $936-944$.

Gao You-Xi, Tang Mao-Cang, Luo Si-We and Shen Zhi. 1981. Some aspects of recent research on the Qinghai-Xizang plateau meteorology. Bull. Am. Meteorol. Soc., 62 (1), 31-35.

Krenak, L. and V. Bhawan. 1945. Recent and past glaciation of Lahaul. Indian Geogr. J., 20 (3), 93-102.

Kumar, S. 1979. Structural analysis of the central crystallines between Rohtang-Manali area, H.P. India. In Recent researches in geolog). Vol. 7. Delhi, Hindustan Publishing Corp., 90-117.

Kumar, S. 1996. Kinematics and timing of collision in the northwest Himalaya in Lahaul and Ladakh region. In Thirtieth International Geographical Congress, 414 August 1996, Beijing, China. Proceedings. Abstract.

Kumar, S. and D. P. Dobhal. 1994. Snout fluctuations of Chhota Shigri glacier, Lahaul and Spiti District, Himachal Pradesh. J. Geol. Soc. India, $44,581-585$.

LiJjjun and Xu Shuying, 1984. The distribution of glaciers on the QinghaiXizang plateau and its relationship to atmospheric circulation. In Miller, K.J., ed. The International Karakorum Project. Proceedings of the International Conference. Vol. 1. Cambridge, Cambridge University Press, 8493.

Purohit, M. K., R. K. Rajput, B. Roy and J. K. Sharma. 1989. Meteorological report of Chhota Shigri glaciers. In Multi disciplinary glacier expedition to Chhota Shirgi glacier, August-September 1989. Dehra Dun, India, Wadia Institute of Himalayan Geology, 60-74. (Technical Report 4.)

Rawat, B. S. and K. K. Purohit. 1988. Geology of the area around Chhota Shigri glacier, Lahaul and Spiti District, H.P. In Multi disciplinary glacier expedition to Chhota Shirgi glacier, July-August 1987. Dehra Dun, India, Wadia Institute of Himalayan Geology, 152-157 (Technical Report 2.) 